\title{
Protein and vegetarian diets
}

I $\mathrm{t}$ is a common myth among both consumers and health professionals that protein needs are difficult to meet on a vegetarian diet. Our objectives in this article are to (i) provide evidence from Australian research to show that vegetarians, while consuming less protein than omnivorous individuals, are meeting recommended intakes of protein; (ii) summarise our current understanding from the literature of the issues of protein quality and protein combining in a vegetarian diet; (iii) show that many plant foods contribute significant amounts of protein to the diet and illustrate how protein needs can easily be met on a vegetarian diet by including a variety of these foods over the course of a day; and (iv) discuss the role of protein in weight management and disease risk, explaining why the lower protein intakes of vegetarians may be beneficial with respect to some health outcomes.

\section{Role of protein}

Proteins are the major structural component of muscle and other body tissues, and are used to produce hormones, enzymes and haemoglobin. An adequate dietary intake of protein is essential for growth and repair of body cells, the normal functioning of muscles, transmission of nerve impulses and immunity. Protein can also be used as energy, but is not the body's preferred energy source, so this occurs only when the amounts of carbohydrate and fats consumed are insufficient, and can be at the expense of tissue maintenance, growth and repair, and immune function. ${ }^{1}$

\section{Amino acids - the building blocks of protein}

Amino acids are classified as being either essential (or indispensable), meaning the body cannot adequately synthesise them and must obtain them from the diet, or non-essential (or dispensable), indicating that the body can make them (Box 1). However, a number of the latter are conditionally indispensable under certain physiological conditions and in certain disease states. In particular, biosynthesis and/or intake of amino acids such as glutamine, arginine and cysteine may be inadequate in meeting physiological requirements during times of stress such as illness, surgery or injury. ${ }^{2}$

Infants and growing children have relatively higher requirements compared to adults for indispensable amino acids and some conditionally indispensable amino acids. ${ }^{1,3}$

\section{Protein quality}

Protein foods that have large amounts of all essential amino acids are often referred to as high-quality proteins. These include foods of animal origin as well as a few plant foods including soy and the grains quinoa and amaranth. Other plant protein sources usually have all of the essential amino acids, but the amounts of one or two of these amino

\section{Summary}

- A vegetarian diet can easily meet human dietary protein requirements as long as energy needs are met and a variety of foods are eaten.

- Vegetarians should obtain protein from a variety of plant sources, including legumes, soy products, grains, nuts and seeds.

- Eggs and dairy products also provide protein for those following a lacto-ovo-vegetarian diet.

- There is no need to consciously combine different plant proteins at each meal as long as a variety of foods are eaten from day to day, because the human body maintains a pool of amino acids which can be used to complement dietary protein.

- The consumption of plant proteins rather than animal proteins by vegetarians may contribute to their reduced risk of chronic diseases such as diabetes and heart disease.

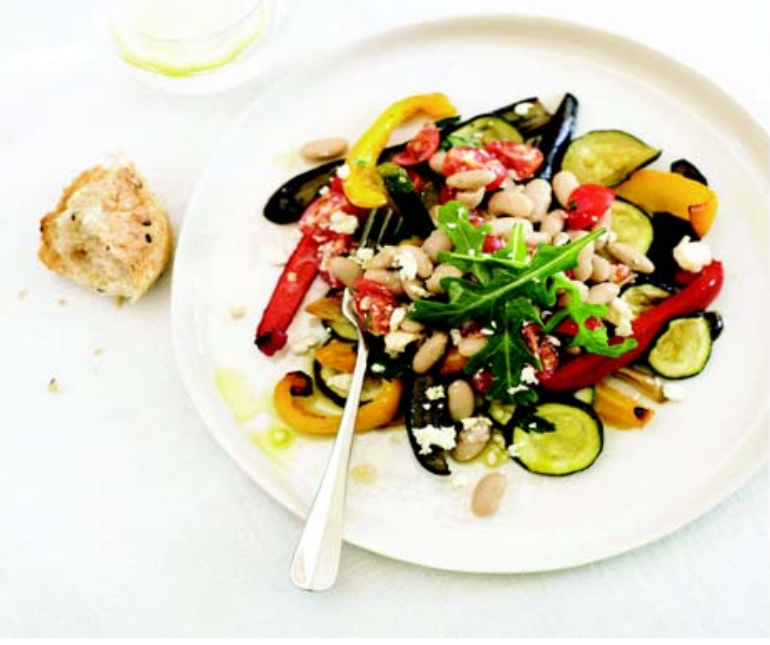

1 Classification of amino acids

\begin{tabular}{ll} 
Essential (indispensable) & Non-essential (dispensable) \\
\cline { 1 - 2 } Phenylalanine & Aspartic acid \\
Valine & Asparagine \\
Threonine & Glutamic acid \\
Isoleucine & Alanine \\
Methionine & Serine \\
\hline Leucine & Cysteine* \\
\hline Lysine & Tyrosine* \\
\hline Histidine & Taurine* \\
& Glycine* \\
& Arginine* \\
& Glutamine* \\
\hline
\end{tabular}

*Conditionally indispensable.
MJA Open 2012: doi: 10.5694/mjaoll.11492 
2 Recommended dietary intake (RDI)* of protein per day ${ }^{10}$

\begin{tabular}{lc}
\hline Sex and age group & RDI \\
\hline Men & $64 \mathrm{~g}$ \\
\hline 19-70 years & $81 \mathrm{~g}$ \\
$>70$ years & \\
Women & $46 \mathrm{~g}$ \\
\hline 19-70 years & $58-60 \mathrm{~g}$ \\
Pregnant & $63-67 \mathrm{~g}$ \\
Breastfeeding & $57 \mathrm{~g}$ \\
$>70$ years & \\
Children & $10 \mathrm{~g}$ \\
0-6 months & $10 \mathrm{~g}$ \\
7-12 months & $14 \mathrm{~g}$ \\
1-3 years & $20 \mathrm{~g}$ \\
$4-8$ years & $40 \mathrm{~g}$ \\
Boys 9-13 years & $65 \mathrm{~g}$ \\
Boys 14-18 years & $35 \mathrm{~g}$ \\
Girls 9-13 years & $45 \mathrm{~g}$ \\
Girls 14-18 years
\end{tabular}

*The RDI is the average daily dietary intake level that is sufficient to meet the nutrient requirements of nearly all healthy individuals $(97 \%-98 \%)$ of a particular sex and life stage.

acids may be low. For example, cereals, and especially wheat, are particularly limited in their lysine content, and legumes are low in methionine. In comparison to animal proteins, plant proteins have lower levels of leucine, methionine, lysine and tryptophan. ${ }^{4}$

The protein quality of a given food can be determined by the Protein Digestibility-Corrected Amino Acid Score (PDCAAS), which evaluates protein quality based on both the amino acid requirements of humans and their ability to digest the food. Most animal proteins (including meat, eggs and milk) have a PDCAAS score close to or equal to 1.0 (the maximum score), as does soy protein, but the scores for other plant proteins are generally lower. ${ }^{5}$ However, a combination of vegetable proteins with

\section{Protein content of a range of plant foods and animal foods*}

\begin{tabular}{|c|c|c|c|}
\hline Plant foods & $\begin{array}{l}\text { Protein } \\
\text { per } 100 \mathrm{~g}\end{array}$ & Animal foods & $\begin{array}{l}\text { Protein } \\
\text { per } 100 \mathrm{~g}\end{array}$ \\
\hline Peanuts, raw & $24.7 g$ & Lamb chop, grilled & $32.6 \mathrm{~g}$ \\
\hline Pumpkin seeds, raw & $24.4 g$ & Beef, fillet, lean, grilled & $31.9 \mathrm{~g}$ \\
\hline Almonds, raw & $20.0 g$ & Beef, round steak, grilled & $31.6 \mathrm{~g}$ \\
\hline Soybeans, cooked & $13.5 g$ & Kangaroo, loin fillet, grilled & $30.7 g$ \\
\hline Tofu & $11.9 \mathrm{~g}$ & Beef, sirloin steak, grilled & $30.3 g$ \\
\hline Lentils, cooked & $6.8 \mathrm{~g}$ & Turkey breast, baked & $29.4 g$ \\
\hline Chickpeas, cooked & $6.3 g$ & Chicken breast, baked & $29.0 \mathrm{~g}$ \\
\hline Baked beans & $4.9 g$ & Pork fillets, trimmed, roasted & $28.5 \mathrm{~g}$ \\
\hline Quinoa, cooked ${ }^{\dagger}$ & $4.4 g$ & Cheese, cheddar & $24.6 g$ \\
\hline Amaranth, cooked ${ }^{\dagger}$ & $3.8 g$ & Salmon, Atlantic, grilled & $24.3 g$ \\
\hline Soy yoghurt & $3.6 g$ & Bream, fillet, baked & $22.0 \mathrm{~g}$ \\
\hline Soy milk & $3.1-4.2 g$ & Egg, whole, boiled & $12.4 \mathrm{~g}$ \\
\hline Brown rice, cooked & $3.0 \mathrm{~g}$ & Yoghurt, low-fat, containing fruit & $5.2 \mathrm{~g}$ \\
\hline
\end{tabular}

adequate energy intake provides enough amino acids of good quality to meet physiological needs. ${ }^{6}$

\section{The protein combining myth}

As most plant foods contain limited amounts of one or more essential amino acids, it was once thought that certain combinations of plant foods had to be eaten at the same meal to ensure a sufficient intake of essential amino acids. While nutritional adequacy can be maintained by including a variety of plant foods which "complement" each other in terms of their amino acid profiles (eg, consuming a mixture of grains and legumes or nuts), it is now known that strict "protein combining" is not necessary, provided energy intake is adequate and a variety of plant foods are eaten each day. ${ }^{6,7}$ The body maintains a pool of indispensable amino acids which can be used to complement dietary proteins; this is one reason why strict protein combining is no longer considered to be necessary.

\section{Recommended dietary intakes}

Nutrient reference values (NRVs) for Australia and New Zealand include a recommendation for an acceptable macronutrient distribution range (AMDR) for protein of $15 \%-25 \%$ of energy intake. ${ }^{10}$ The AMDR is an estimate of the range of intake for each macronutrient for individuals (expressed as a percentage of total energy intake) that would allow for an adequate intake of all the other nutrients. The NRV document notes that while, on average, only $10 \%$ of energy need be consumed as protein to meet the physiological need for protein, this level is insufficient to allow for estimated average requirements (EARs) for micronutrients when consuming foods commonly eaten in Australia and New Zealand. ${ }^{10}$ In other words, while consuming lower amounts of protein-rich foods could meet the body's protein needs, it would not provide sufficient amounts of other nutrients found in these foods including iron, zinc, calcium and vitamin $B_{12}$. Recommended dietary intakes (RDIs) for protein for different sex and age groups are shown in Box 2 .

The 1995 National Nutrition Survey (NNS) for Australians found the mean daily protein intake for those aged 19 years and over was $91 \mathrm{~g}$ or $17 \%$ of energy. ${ }^{11}$ Mean intakes for those aged 19 years and over were $109 \mathrm{~g}$ for men and $74 \mathrm{~g}$ for women - amounts well above the RDI. Intakes were at least $60 \%$ greater than the RDI for most groups, except those aged 65 years and over, whose mean intakes were $84 \mathrm{~g}$ for men and $64 \mathrm{~g}$ for women; although relatively lower, these amounts were still adequate in terms of RDI. Children and adolescents were eating close to or more than double their RDIs and, while pregnant women were not surveyed separately, the average intake for women would be adequate to meet the RDI during pregnancy or lactation.

In general, studies of Australian vegetarians have found that their protein intakes are significantly lower than those of omnivores. A study of Australian men aged 20-50 years found that those on a lacto-ovo-vegetarian (LOV) diet consumed $80 \mathrm{~g}$ of protein per day (16\% of energy) and vegans consumed $81 \mathrm{~g}$ of protein per day (12\% of energy) compared with $108 \mathrm{~g}$ (17\% of energy) for omnivores. ${ }^{12}$ 
Among women aged 18-45 years, those following a vegetarian diet (LOV and vegan) had a mean protein intake of $54 \mathrm{~g}$ per day (14\% of energy) compared with $67 \mathrm{~g}$ per day (18\% of energy) for omnivores. ${ }^{13}$ While the reported protein intakes of vegetarians are significantly lower, it is clear from these studies that most vegetarians and vegans still meet the RDI for protein, and intakes are within the AMDR.

\section{Do protein requirements differ for vegetarians?}

Protein requirements for healthy adults have not been found to differ according to whether dietary protein is predominantly from animal, vegetable or mixed protein sources provided soy protein or a variety of other vegetable proteins is consumed. ${ }^{14}$ However, studies comparing single sources of protein have found significant differences between plant and animal sources, particularly with cereal proteins such as wheat and rice, ${ }^{4,15-17}$ as their low lysine content may be a limiting factor. Consequently, if protein intake was to be restricted to a single plant source, such wheat, rice or legumes (other than soy), then the amount of protein required to meet essential amino acid needs may be increased. ${ }^{7}$

\section{Protein in a vegetarian diet}

As discussed above, while vegetarian diets may provide less protein than a non-vegetarian diet, they are still able to meet protein requirements. If a vegetarian diet is planned to meet the requirements for essential micronutrients, including iron, zinc, calcium and vitamin $\mathrm{B}_{12}$, it is likely that protein needs will be exceeded. Most plant foods contain some protein, with the best sources being legumes, soy foods (including soy milk, soy yoghurt, tofu and tempeh), Quorn (mycoprotein), nuts and seeds. Grains and vegetables also contain protein, but in smaller amounts. Box 3 shows the protein content of common plant foods and a comparison with animal protein sources.

Health professionals should encourage vegetarians to include a variety of protein-rich foods each day, not only to ensure an adequate intake of protein, but also to provide sufficient iron, zinc, calcium and vitamin $B_{12}$. This range of foods should include:

- legumes such as soybeans, chickpeas, lentils, kidney beans, split peas and baked beans;

- wholegrains such as brown rice, buckwheat, polenta, quinoa and amaranth;

- soy products such as soy beverages, soy yoghurt, and tofu;

- nuts and seeds; and

- dairy foods and eggs (for those following an LOV diet).

Box 4 shows a sample meal plan designed to meet daily protein requirements as well as the requirements for all micronutrients within an acceptable energy intake for a woman aged $31-50$ years.

\section{The benefits of plant protein}

While the lower protein intake and quality of protein in a vegetarian diet is often believed to be a concern, there is increasing evidence that consuming protein from plant rather than animal sources may, in fact, be one of the reasons why vegetarians generally have a lower risk of overweight, obesity and chronic disease. In comparison to

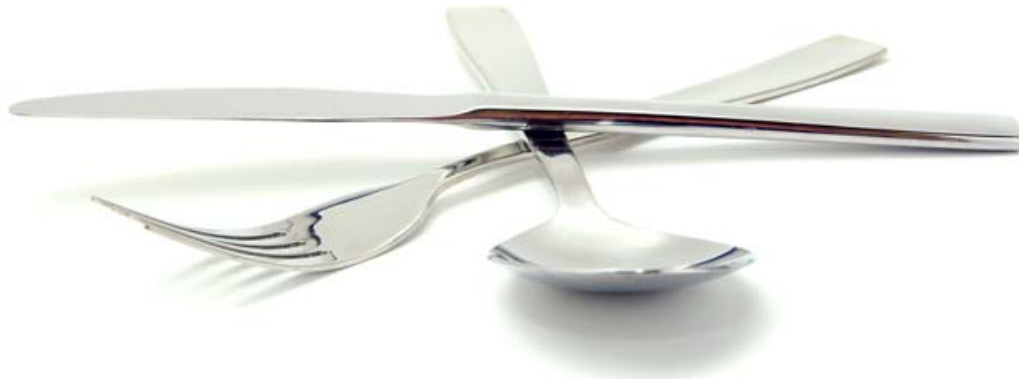

4 A sample vegetarian meal plan designed to meet the protein and micronutrient requirements of a 31-50year-old woman, showing protein content of the foods*

\begin{tabular}{ll} 
Meal & Protein content \\
\hline Breakfast & \\
Bowl of cereal with fruit, and poached egg on toast & \\
2 wholegrain wheat biscuits & $3.6 \mathrm{~g}$ \\
4 strawberries & $0.8 \mathrm{~g}$ \\
$10 \mathrm{~g}$ chia seeds & $2.0 \mathrm{~g}$ \\
$1 / 2$ cup low-fat soy milk & $4.6 \mathrm{~g}$ \\
1 slice multigrain toast & $3.4 \mathrm{~g}$ \\
1 poached egg (omega-rich egg) & $6.0 \mathrm{~g}$ \\
\hline Snack &
\end{tabular}

Nuts and dried fruit

30 g cashews

$5.1 \mathrm{~g}$

6 dried apricot halves

$0.9 \mathrm{~g}$

\section{Lunch}

Chickpea falafel wrap

$I$ wholemeal pita flatbread

$6.2 \mathrm{~g}$

1 chickpea falafel

$9.1 \mathrm{~g}$

30 g hummus

$2.8 \mathrm{~g}$

1/2 cup tabouli

$2.7 \mathrm{~g}$

Salad

$0.8 \mathrm{~g}$

\section{Snack}

Banana and wheatgerm smoothie

3/4 cup low-fat soy milk

$6.8 \mathrm{~g}$

2 teaspoons wheatgerm

$0.7 \mathrm{~g}$

1 banana

$1.4 \mathrm{~g}$

\section{Dinner}

Stir-fry greens with tofu and rice

$100 \mathrm{~g}$ tofu

$1.9 \mathrm{~g}$

2 spears asparagus, 1/3 cup bok choy and

$25 \mathrm{~g}$ snow peas

$2.4 \mathrm{~g}$

$12 \mathrm{~g}$ cashews

$2.0 \mathrm{~g}$

1 cup cooked brown rice

6.68

\section{Snack}

Fortified malted chocolate beverage

1 cup low-fat soy milk

9.18

$10 \mathrm{~g}$ fortified malted chocolate powder

1.38

\section{Total protein}

$90.2 \mathrm{~g}$

* Source: FoodWorks 2009 (incorporating Food Standards Australia New Zealand's AUSNUT [Australian Food and Nutrient Database] 1999)،

Xyris Software, Brisbane, Qld.
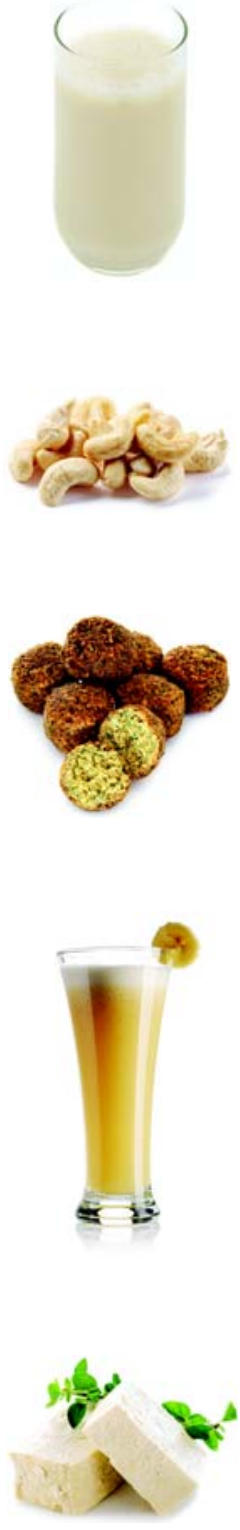


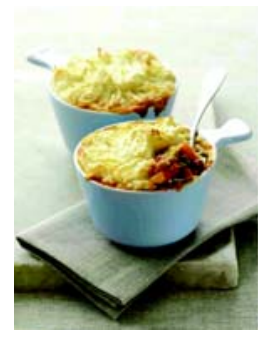

protein foods of animal origin, most plant protein sources are lower in saturated fat, free of cholesterol and haem iron, higher in fibre, and are good sources of antioxidants and phytochemicals, all of which may contribute to a reduced disease risk.

A number of studies have shown that a higher intake of protein, particularly animal protein, in infants and early childhood may increase the risk of overweight and obesity in later life..$^{20-22}$ In adults, the European Prospective Investigation in Cancer and Nutrition (EPIC)-Oxford study compared weight gain over 5 years among almost 22000 meat-eating, fish-eating, vegetarian, and vegan men and women; it found that weight gain was lowest in the vegan group and in those who, during follow-up, had changed to a diet containing fewer animal foods. ${ }^{23}$ The study also found that meat-eaters had the highest body mass index (BMI) and vegans the lowest BMI, while fish-eaters and vegetarians had similar, intermediate mean BMIs. ${ }^{24}$ Differences in macronutrient intakes accounted for about half the difference in mean BMI between vegans and meat-eaters, with high protein and low fibre intakes most strongly associated with increasing BMI. ${ }^{24}$ More recently, a study of several cohorts from the EPIC study participating in the diet, genes and obesity (Diogenes) project reported that in contrast to plant protein intake, total protein and protein from animal sources was positively associated with subsequent weight gain although there was no overall association between dietary protein and change in waist circumference. ${ }^{25}$

While the safety of high-protein, low-carbohydrate diets is debated, the type of protein in such diets may be important. A report of two cohort studies found that a lowcarbohydrate diet based on animal sources was associated with higher all-cause mortality, while a vegetable-based low-carbohydrate diet was associated with lower all-cause and cardiovascular disease mortality rates. ${ }^{26}$ Other studies have shown benefits of plant protein compared with animal protein for lowering blood pressure ${ }^{27,28}$ and the risk of type 2 diabetes ${ }^{29,30}$ and of ischaemic heart disease in healthy men. ${ }^{31}$ Furthermore, consumption of soy protein may slow the progression of kidney disease compared with consumption of animal protein, particularly red meat. ${ }^{32}$

\section{Conclusion}

Vegetarians who eat a range of plant foods can easily meet their protein requirements, even though the protein content of vegetarian diets is usually lower than that of omnivorous diets. Most Australians eat significantly more protein than is required. The consumption of plant protein rather than animal protein may play a role in weight management and reducing chronic disease risk.

Competing interests: Kate Marsh previously consulted for Nuts for Life (Horticulture Australia). Elizabeth Munn consults for Nuts for Life and Sanitarium Health and Wellbeing, and has previously consulted for Go Grains Health and Nutrition, Avocados Australia, Healthy Food Guide magazine, and the Almond Board of Australia. Go Grains Health and Nutrition and Nuts for Life are providing a contribution towards the cost of publishing this supplement.

Provenance: Commissioned by supplement editors; externally peer reviewed.

1 Joint WHO/FAO/UNU Expert Consultation. Protein and amino acid requirements in human nutrition. World Health Organ Tech Rep Ser 2007; 935: 1-265.

2 Soeters PB, van de Poll MC, van Gemert WG, Dejong CH. Amino acid adequacy in pathophysiological states. J Nutr 2004; 134 (6 Suppl): 1575S-1582S.
3 Imura K, Okada A. Amino acid metabolism in pediatric patients. Nutrition 1998; 14: 143-148.

4 Young VR, Fajardo L, Murray E, et al. Protein requirements of man: comparative nitrogen balance response within the submaintenance-tomaintenance range of intakes of wheat and beef proteins. J Nutr 1975; 105: 534-542

5 Sarwar G, McDonough FE. Evaluation of protein digestibility-corrected amino acid score method for assessing protein quality of foods. J Assoc Off Anal Chem 1990; 73: 347-356.

6 Craig WJ, Mangels AR. Position of the American Dietetic Association: vegetarian diets. J Am Diet Assoc 2009; 109: 1266-1282.

7 Young VR, Pellett PL. Plant proteins in relation to human protein and amino acid nutrition. Am J Clin Nutr 1994; 59 (5 Suppl): 1203S-1212S

8 Fuller MF, Reeds PJ. Nitrogen cycling in the gut. Annu Rev Nutr 1998; 18 385-411.

9 Millward DJ, Forrester T, Ah-Sing E, et al. The transfer of $15 \mathrm{~N}$ from urea to lysine in the human infant. Br J Nutr 2000; 83: 505-512.

10 Australian Government Department of Health and Ageing, National Health and Medical Research Council; New Zealand Ministry of Health. Nutrient reference values for Australia and New Zealand including recommended dietary intakes. Canberra: NHMRC, 2005. http:// www.nhmrc.gov.au/guidelines/publications/n35-n36-n37 (accessed May 2012).

11 Australian Bureau of Statistics. National Nutrition Survey. Selected Highlights, Australia, 1995. Canberra: ABS, 1995: 20. (ABS Cat. No. 4802.0.) http://www.abs.gov.au/AUSSTATS/abs@.nsf/DetailsPage/ 4802.01995? OpenDocument (accessed Apr 2012).

12 Wilson AK, Ball MJ. Nutrient intake and iron status of Australian male vegetarians. Eur J Clin Nutr 1999; 53: 189-194.

13 Ball MJ, Bartlett MA. Dietary intake and iron status of Australian vegetarian women. Am J Clin Nutr 1999; 70: 353-358.

14 Rand WM, Pellett PL, Young VR. Meta-analysis of nitrogen balance studies for estimating protein requirements in healthy adults. Am J Clin Nutr 2003: 77: 109-127.

15 Inoue G, Fujita Y, Niiyama Y. Studies on protein requirements of young men fed egg protein and rice protein with excess and maintenance energy intakes. J Nutr 1973; 103: 1673-1687.

16 Barzel US, Massey LK. Excess dietary protein can adversely affect bone. J Nutr 1998; 128: 1051-1053.

17 Remer T, Manz F. Estimation of the renal net acid excretion by adults consuming diets containing variable amounts of protein. Am J Clin Nutr 1994; 59: 1356-1361.

18 Food Standards Australia New Zealand. NUTTAB 2010 online searchable database. http://www.foodstandards.gov.au/consumer information/ nuttab2010/nuttab2010onlinesearchable database/onlineversion.cfm (accessed Feb 2012).

19 United States Department of Agriculture. National Nutrient Database for Standard Reference. http://www.nal.usda.gov/fnic/foodcomp/search/ (accessed Apr 2012).

20 Günther AL, Buyken AE, Kroke A. Protein intake during the period of complementary feeding and early childhood and the association with body mass index and percentage body fat at $7 \mathrm{y}$ of age. Am J Clin Nutr 2007: 85: 1626-1633.

21 Günther AL, Remer T, Kroke A, Buyken AE. Early protein intake and later obesity risk: which protein sources at which time points throughout infancy and childhood are important for body mass index and body fat percentage at 7 y of age? Am J Clin Nutr 2007; 86: 1765-1772.

22 Koletzko B, von Kries R, Closa R, et al; European Childhood Obesity Trial Study Group. Lower protein in infant formula is associated with lower weight up to age 2 y: a randomized clinical trial. Am J Clin Nutr 2009; 89 1836-1845.

23 Rosell M, Appleby P. Spencer E, Key T. Weight gain over 5 years in 21,966 meat-eating, fish-eating, vegetarian, and vegan men and women in EPICOxford. Int J Obes (Lond) 2006; 30: 1389-1396.

24 Spencer EA, Appleby PN, Davey GK, Key TJ. Diet and body mass index in 38000 EPIC-Oxford meat-eaters, fish-eaters, vegetarians and vegans. Int I Obes Relat Metab Disord 2003:27: 728-734.

25 Halkjær J, Olsen A, Overvad K, et al. Intake of total, animal and plant protein and subsequent changes in weight or waist circumference in European men and women: the Diogenes project. Int J Obes (Lond) 2011 35: $1104-1113$.

26 Fung TT, van Dam RM, Hankinson SE, et al. Low-carbohydrate diets and all-cause and cause-specific mortality. Ann Intern Med 2010; 153: 289-298.

27 Elliott P, Stamler J, Dyer AR, et al. Association between protein intake and blood pressure the INTERMAP Study. Arch Intern Med 2006; 166: 79-87.

28 Altorf-van der Kuil W, Engberink MF, Vedder MM, et al. Sources of dietary protein in relation to blood pressure in a general Dutch population. PLoS One 2012; 7: e30582.

29 Pounis GD, Tyrovolas S, Antonopoulou M, et al. Long-term animal-protein consumption is associated with an increased prevalence of diabetes among the elderly: the Mediterranean Islands (MEDIS) study. Diabetes Metab 2010; 36: 484-490.

30 Sluijs I, Beulens JW, van der A DL, et al. Dietary intake of total, animal, and vegetable protein and risk of type 2 diabetes in the European Prospective Investigation into Cancer and Nutrition (EPIC)-NL study. Diabetes Care 2010; 33: 43-48.

31 Preis SR, Stampfer MJ, Spiegelman D, et al. Dietary protein and risk of ischemic heart disease in middle-aged men. Am J Clin Nutr 2010: 92. 1265-1272.

32 Anderson JW. Beneficial effects of soy protein consumption for renal function. Asia Pac J Clin Nutr 2008; 17 Suppl 1: 324-328. 